\title{
Two Hepatic Cytoplasmic Protein Fractions, Y and Z, and Their Possible Role in the Hepatic Uptake of
} Bilirubin, Sulfobromophthalein, and Other Anions

\author{
A. J. Levi, Z. Gatmattan, and I. M. Arias \\ From the Department of Medicine, Albert Einstein College of Medicine and \\ Bronx Municipal Hospital Center, New York 10461
}

\begin{abstract}
A B S T RACT Two hepatic cytoplasmic protein fractions, designated $\mathrm{Y}$ and $\mathrm{Z}$, which bind sulfobromophthalein (BSP), bilirubin, and other organic anions, have been separated by G75 Sephadex gel filtration. The physiologic role of these protein fractions has been investigated. They are present in the $110,000 \mathrm{~g}$ supernatant fraction from the livers of all the species tested (rats, mice, guinea pigs, Rhesus monkeys, sheep, and man). Tissues which do not preferentially extract BSP or bilirubin from plasma do not contain these fractions, with the exception of small intestinal mucosa which contains $\mathrm{Z}$. Anion binding by $\mathrm{Y}$ and $\mathrm{Z}$ fractions is not due to contamination with albumin. These fractions are responsible for the cytoplasmic localization of bilirubin in Gunn rats, and the fractions bind bilirubin, BSP, or indocyanine green (ICG), whether given in vivo or added in vitro to liver supernate from normal rats. Flavaspidic acid- $N$-methylglucaminate, bunamiodyl, and iodipamide, drugs known to interfere with the hepatic uptake mechanism, compete with bilirubin and BSP for binding to $Z$. These proteins appear to be important in the transfer of organic anions from plasma into the liver and provide a tool for the investigation of hepatic uptake mechanisms.
\end{abstract}

\section{INTRODUCTION}

In comparison with other organs, the liver is preferentially able to transfer bilirubin, sulfobromophthalein (BSP), and other organic anions from the plasma to

Portions of this work were presented at the Annual Meeting of The American Society for Clinical Investigation, Atlantic City, N. J., 1968.

Dr. Levi is a Fellow of the Nuffield Foundation, London, Great Britain.

Received for publication 9 May 1969 and in revised form 9 July 1969. the parenchymal cell. The basis for the hepatic selectivity, the mechanism of the transfer process and its anion specificity are not understood. Special properties of the plasma membrane or special binding properties of cytoplasmic proteins might be involved in the transfer process and in the determination of its specificity.

5 min after the intravenous injection of bilirubin into a rat, over $50 \%$ of injected bilirubin is in the liver and approximately two-thirds is recovered in the $100,000 \mathrm{~g}$ supernatant fraction of liver homogenates $(1,2)$. Unconjugated bilirubin is relatively insoluble in aqueous media at physiologic $\mathrm{pH}(3,4)$. Although bilirubin is bound to albumin in plasma (5), only small amounts of albumin are present in liver cells (6), and the rate of transfer of bilirubin into liver is greater than the corresponding rate of transfer of albumin (1). These observations suggest that bilirubin in the cytoplasm of liver cells is primarily bound to protein(s) other than albumin $(1,2,7,8)$.

This communication concerns the identification of two hepatic cytoplasmic protein fractions, designated as $\mathrm{Y}$ and $Z$, which account for the tissue, cellular, and subcellular localization of injected bilirubin and BSP. The organ and species specificities of these protein fractions have been defined and a variety of genetic and pharmacologic models have been investigated to elucidate the possible role of $\mathrm{Y}$ and $\mathrm{Z}$ in organic anion transfer from plasma into the liver cell.

\section{METHODS}

The majority of studies were performed using adult Sprague Dawley rats of either sex. The animals were anesthetized with ether and the liver was removed, immediately washed in ice-cold isotonic saline, weighed, and perfused through the hepatic veins until all traces of blood were washed out. A $25 \%$ homogenate was prepared in $0.25 \mathrm{M}$ sucrose- $0.01 \mathrm{M}$

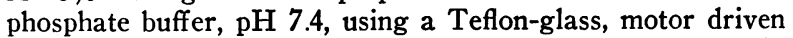
homogenizer (Arthur H. Thomas Co., Philadelphia, Pa.). 
The homogenate was centrifuged at $2^{\circ} \mathrm{C}$ in a Beckman Spinco model $\mathrm{L}$ ultracentrifuge at $110,000 \mathrm{~g}(\max )$ for 120 min. The supernatant fraction was separated from the pellet and surface lipid and used immediately or stored at $-20^{\circ} \mathrm{C}$. Kidney, muscle, and spleen were similarly treated. Rat kidney and muscle and monkey liver sometimes require initial disruption using a Virtis homogenizer. Rat brain, small intestine, colon, stomach, and skeletal muscle were homogenized without prior perfusion. Jejunal and ileal mucosa was obtained by scraping the intestine between glass slides into $0.25 \mathrm{~m}$ sucrose, $\mathrm{pH}$ 7.4. The submucosal, muscular, and serosal layer was separately homogenized. Rat bile was collected in the dark on ice after cannulation of the common bile duct. Rat plasma was obtained from blood removed by venepuncture. $2 \times 10^{8}$ rat liver cells were prepared according to Howard, Christensen, Gibbs, and Pesch (9), homogenized, and treated as described. Supernatant liver fraction was also prepared in the same manner from adults of the following species: Wistar and glucuronyl transferase-deficient (Gunn) rats (10) of either sex; normal Southdown rams and mutants with defective hepatic uptake of various organic anions (11) ; male rhesus monkeys; inbred mice of either sex from several strains (C57BL/6, $\mathrm{W} / \mathrm{Wv}, \mathrm{DBA} / 2 \mathrm{~J}, \mathrm{Dw} / \mathrm{dw}$, and $\mathrm{LG} / \mathrm{J}$ obtained from the Jackson Laboratory, Bar Harbor, Maine); and Hartley guinea pigs of either sex. Normal human liver was obtained either at surgery or at autopsy performed promptly after death. From two to eight studies were performed with each tissue and comparable results obtained.

The supernate was eluted from Sephadex G75 to detect protein fractions with a high affinity for various organic anions. From 0 to $12 \mu$ moles of BSP, indocyanine green (ICG), Evans blue, bilirubin, or bilirubin $-{ }^{8} \mathrm{H}$ were added to measured aliquots of bile, serum, or supernate obtained from 1 to $4 \mathrm{~g}$ of tissue and thoroughly mixed. Bilirubin ${ }^{8} \mathrm{H}$ (specific activity $79.5 \mu \mathrm{c} / \mu$ mole) was prepared, equilibrated, and purified as previously described $(1,2)$. The supernatant fraction-organic anion mixtures were placed on a Sephadex G75 column equilibrated with $0.01 \mathrm{M}$ phosphate buffer,

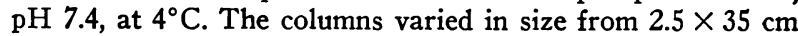
to $3.2 \times 96 \mathrm{~cm}$. Elution was performed using the same buffer and a pump-driven, upward flow system which permitted accurate timed collections of constant volume (3-6 ml/tube). The flow rate was $20-40 \mathrm{ml} / \mathrm{hr}$. The following elution patterns were monitored using a Beckman DU spectrophotometer : protein at $280 \mathrm{~m} \mu, \mathrm{BSP}$ at $580 \mathrm{~m} \mu$ (after alkalinization with $\mathrm{NaOH}$ ), bilirubin at $460 \mathrm{~m} \mu$, Evans blue at $620 \mathrm{~m} \mu$, and ICG at $800 \mathrm{~m} \mu$. Appropriately diluted solutions of the anions were used as standards to convert optical density to micromoles. Protein was quantitated by the method of Lowry, Rosebrough, Farr, and Randall (12) or 280:260 absorption ratio (13). Bilirubin was also quantitated by the Malloy-Evelyn modification of the van den Bergh reaction (14) and when bilirubin $-{ }^{3} \mathrm{H}$ was used by quenchcorrected, internally standardized counting in a refrigerated liquid scintillation counting system (Nuclear-Chicago Corporation, Des Plaines, Ill.) as previously described (2). Supernate bilirubin was measured by Hargreaves' method (15).

The heat stability of the anion-binding proteins was investigated by incubating an aliquot of supernate derived from $1 \mathrm{~g}$ rat liver in a Dubnoff incubator bath at each of the following temperatures, $40,50,55,60,70$, and $80^{\circ} \mathrm{C}$, for $10 \mathrm{~min}$. The precipitated protein was removed by centrifugation at $10,000 \mathrm{rpm}$ for $10 \mathrm{~min}$. The supernate was mixed with 3.0 $\mu$ moles BSP and eluted as described. BSP bound by each fraction was quantitated as described subsequently.

The localization of rat albumin in eluates from Sephadex G75 columns was determined in three ways. (a) $5 \mu \mathrm{c}$ bilirubin $-{ }^{8} \mathrm{H}$ was added to the supernatant fraction from $5.5 \mathrm{~g}$ of Gunn rat liver and eluted as described. Each tube of eluate associated with yellow pigment was divided into aliquots. The protein in one aliquot was precipitated with an equal volume of cold $10 \%$ trichloracetic acid, collected on glass filters, washed, dried, added to scintillator, and counted (2). A further aliquot was mixed with rabbit anti-rat albumin gamma globulin, centrifuged, and the supernate separated and prepared for counting as described. $0.35 \mathrm{mg}$ of rabbit anti-rat albumin gamma globulin precipitated $1.0 \mathrm{mg}$ purified rat albumin.

(b) Aliquots of the presumed albumin fraction contained a protein which after concentration by lyophilization migrated as albumin on electrophoresis on acrylamide gel ( $5 \%$ ) in barbital buffer, ionic strength $0.075 \mathrm{pHI} 8.6$, in a vertical gel electrophoresis apparatus. ${ }^{1}$

(c) $3-10 \mathrm{mg}$ purified rat albumin (Pentex) was mixed with $6 \mu$ moles BSP and aliquots of rat liver supernate (derived from $2 \mathrm{~g}$ liver) and eluted as described. The effect of the added albumin on the BSP binding fractions was measured spectrophotometrically.

Reproducibility of the amount of BSP bound by $\mathrm{Y}$ and $\mathrm{Z}$ after elution of supernate from Sephadex G75 was investigated by performing repeated studies on five columns. $3 \mu$ moles $\mathrm{BSP} / \mathrm{g}$ was added to aliquots of supernate from 0.5 to $2 \mathrm{~g}$ of rat liver containing $40 \mathrm{mg}$ protein $/ \mathrm{g}$. The mixture was eluted as described. The results were expressed as micromoles BSP per milligram protein in the peak tubes in the $\mathrm{Y}$ and $\mathrm{Z}$ fractions and the micromoles BSP in each fraction per gram liver calculated by triangulation from the area under each peak ([peak BSP concentration - base line BSP concentration] $\times$ volume per tube $\times$ No. of tubes $\times 0.5$ ). This method proved reproducible for columns of equal size when constant amounts of protein were used. The buffer $\mathrm{pH}$ and tonicity, elution flow rate, and temperature were kept constant.

The proteins within the $Y$ and $Z$ fractions responsible for the organic anion binding have not been purified in sufficient quantity for binding studies by classical techniques. Binding studies were, therefore, performed using Sephadex G75 gel filtration, varying amounts of BSP, and equal aliquots of liver supernate prepared from three adult male Sprague Dawley rats. Each aliquot represented supernate from $1.34 \mathrm{~g}$ liver and contained $25 \mathrm{mg}$ protein. From 0.037 to $6.0 \mu$ moles BSP was added in vitro and each aliquot was fractionated on the same Sephadex G75 column $(3.2 \times$ $51.5 \mathrm{~cm}$ ) under standard conditions at a flow rate of 34.7 $\mathrm{ml} / \mathrm{hr}$. The three to five tubes containing the maximum amounts of BSP in the $\mathrm{Y}$ and $\mathrm{Z}$ fractions were combined and protein and dye concentrations were determined. The results were expressed as micromoles BSP per milligram protein in each fraction.

The distribution of BSP in $\mathrm{Y}$ and $\mathrm{Z}$ fractions of rat liver supernate as a function of time after intravenous injection of the dye was studied. Five male Sprague Dawley rats weighing $240-370 \mathrm{~g}$ were separately injected intravenously with $6 \mu$ moles $\mathrm{BSP} / 100 \mathrm{~g}$ body weight. They were subsequently killed at $0.5,1.5,3.0,5.75$, or $8.0 \mathrm{~min}$, and the livers were processed and fractionated in the previously described manner. The results were expressed as micromoles BSP per

${ }^{1}$ E. C. Apparatus Corporation, Philadelphia, $\mathrm{Pa}$. 


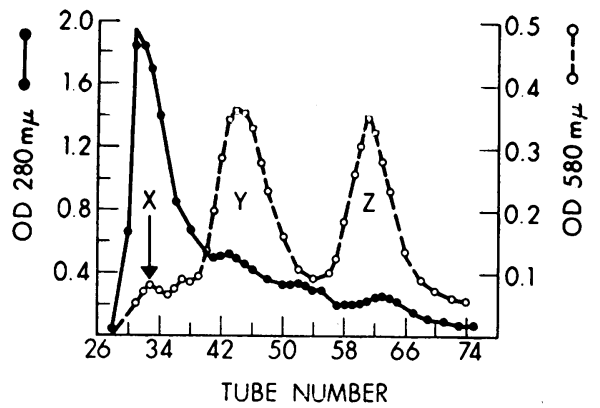

FIGURE 1 The $\mathrm{X}, \mathrm{Y}$, and $\mathrm{Z}$ sulfobromophthalein (BSP)binding protein fractions from $110,000 \mathrm{~g}$ (max) supernate from $2 \mathrm{~g}$ rat liver containing $58 \mathrm{mg}$ protein with $2.4 \mu$ moles BSP added in vitro and eluted from a column of Sephadex G75 $(3.2 \times 55 \mathrm{~cm})$ at a flow rate of $32.8 \mathrm{ml} / \mathrm{hr}$. Collections were $4.9 \mathrm{ml} /$ tube. Optical density at $280 \mathrm{~m} \mu$ indicates protein and at $580 \mathrm{~m} \mu$ after alkalinization indicates BSP.

milligram protein in the $\mathrm{Y}$ and $\mathrm{Z}$ fractions. BSP in liver homogenates was determined by the method of Philip, Grodsky, and Carbone (16) after perfusion of the organ. The results were read against a standard curve of BSP added in comparable amounts to a normal liver homogenate. Heparinized blood specimens were obtained immediately before removal of the liver, and BSP concentration was estimated in plasma after alkalinization. The plasma BSP concentration from each rat was plotted semilogarithmically against time and a single $t_{1}$ determined by best fit analysis.

Studies of organic anion binding in vitro were performed using bilirubin, BSP, ICG, and Evans blue added to aliquots of rat liver supernate and eluted from Sephadex G75 columns. At least three studies or series of studies were performed with each anion varying the column size and amount of applied supernate. Representative studies using columns of comparable size are shown in Table II.

The distribution of ICG or Evans blue in the $\mathrm{Y}$ and $\mathrm{Z}$ fractions of liver supernate was investigated after intravenous injection and processing in the usual manner. The doses of the organic anions and the times of sacrifice are shown in Table III.

Two male Sprague Dawley rats weighing 200 and $210 \mathrm{~g}$ were injected respectively with bilirubin ${ }^{3} \mathrm{H} \quad 150,000 \mathrm{cpm}$ with or without $6.2 \mu$ moles unlabeled bilirubin. The animals were killed $5 \mathrm{~min}$ after injection and the liver was processed. From appropriate tubes, $0.5 \mathrm{ml}$ of the Sephadex G75 eluate was evaporated and counted as previously described.

The effect of flavaspidic acid- $N$-methylglucaminate, ${ }^{2}$ bunamiodyl ${ }^{3}$ (3-3-butyrlamino 2,4,6-triodophenyl-2-ethyl sodium acrylate), iodipamide ${ }^{4}$ (bis- $N$-methylglucamine salt of N,N ${ }^{1}$ adipyl-bis [3-amino-2,4,6-triodobenzoic acid]), novobiocin $^{5}$ probenecid ${ }^{6} \quad(p$-(dipropylsulfamoyl)-benzoic acid), and $X 5079 \mathrm{C}^{7}$ on the binding of BSP or bilirubin by the $Y$ and $Z$ protein fractions was studied in vivo and in vitro. The drugs were prepared for use by dissolving in

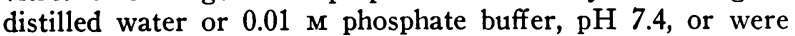
in neutral solution as supplied by the manufacturer.

${ }^{2}$ Prepared and donated by Dr. Esa Aho, Turku, Finland.

${ }^{3}$ E. Fougera and Co., Inc., Hicksville, N. Y.

${ }^{4}$ E. R. Squibb \& Sons, New Brunswick, N. J.

- Upjohn Co., Carle Place, Long Island, N. Y.

Merck \& Co, Inc., New York.

${ }^{7}$ Hoffman-La Roche, Inc., Nutley, N. J.
For studies in vitro, aliquots of a standard supernate were prepared, BSP and the drug under investigation were added, and the mixture eluted in the manner previously described. The quantities used are shown in Fig. 10 and Table IV. The effect of $0-51 \mu$ moles taurocholic acid (dissolved in $0.01 \mathrm{M}$ sodium phosphate buffer, $\mathrm{pH} 7.4$ ) on the binding of $\mathrm{BSP}$ by the $\mathrm{Y}$ and $\mathrm{Z}$ protein fraction was investigated in vitro in a similar manner. The results were expressed as micromoles BSP bound by each fraction.

For the studies in vivo, flavaspidic acid- $N$-methyl-glucaminate, bunamiodyl, iodipamide, novobiocin, and probenecid were separately injected intravenously into Gunn rats at the dosages shown in Table V. The time of removal of the liver was chosen on the basis of published data showing when each drug caused a hepatic uptake defect (17-22). The results are expressed as micromoles bilirubin in each fraction and were compared with values found in control animals when supernate, also derived from $4 \mathrm{~g}$ liver, was eluted from the similar columns. In some studies, serum (14) and supernate (15) bilirubin concentration were measured.

\section{RESULTS}

Sephadex G75 gel filtration of rat liver supernate with BSP added in vitro yielded an elution pattern shown in Fig. 1. There was variable dye binding, labeled $\mathrm{X}$, by high molecular weight proteins in the void volume. In the remaining tubes there was considerably less protein but preferential localization of BSP binding to two fractions labeled $Y$ and $Z$. Free BSP was eluted from the column in later fractions not shown in the figure. This pattern of BSP binding was not changed when Tris- $\mathrm{HCl}, \mathrm{pH} 7.4$, replaced phosphate buffer or when the molarity of the phosphate buffer was increased from 0.01 to $0.1 \mathrm{~mole} / \mathrm{liter}$, or when the $\mathrm{pH}$ was decreased from 7.4 to 6.5 , or whether the temperature at which column chromatography was performed was $4^{\circ} \mathrm{C}$ or at

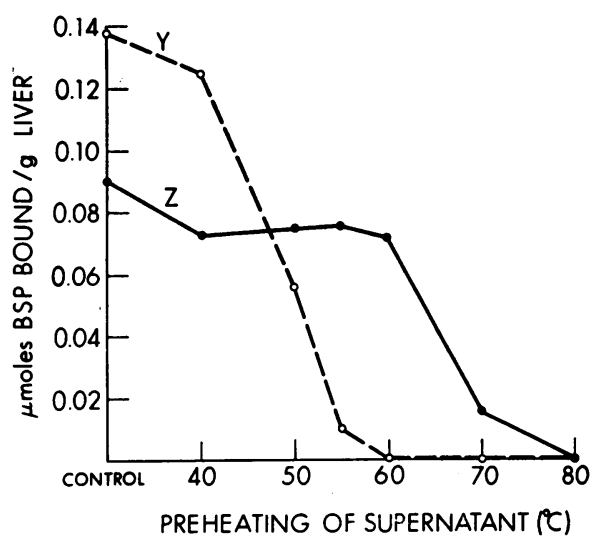

FIgURE 2 The effect of preheating rat liver supernate on BSP binding by $\mathrm{Y}$ and $\mathrm{Z}$ fractions in vitro. Each supernatant aliquot was derived from $1 \mathrm{~g}$ liver and was mixed with 3.0 $\mu$ moles BSP before elution from a column of Sepha$\operatorname{dex} \operatorname{G75}(2.5 \times 37 \mathrm{~cm})$ at a flow rate of $20 \mathrm{ml} / \mathrm{hr}, 3 \mathrm{ml} / \mathrm{tube}$. For other details see text. 


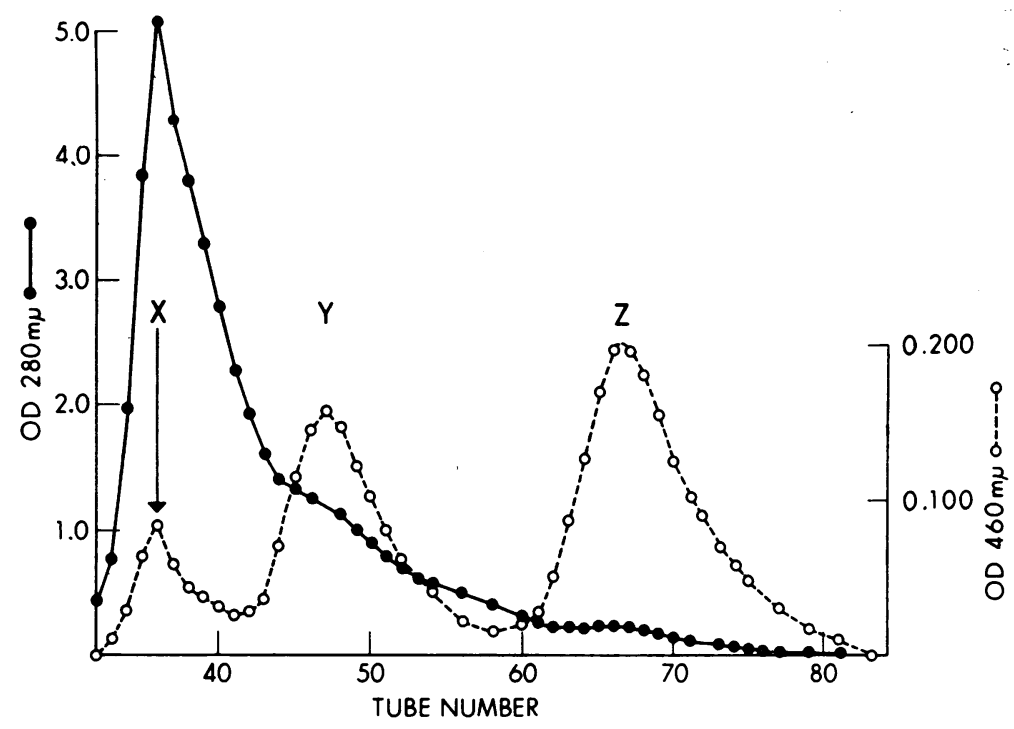

FIGURE 3 Elution pattern of protein (OD $280 \mathrm{~m} \mu$ ) and yellow pigments (OD $460 \mathrm{~m} \mu$ ) from the supernate from $4 \mathrm{~g}$ Gunn rat liver. Sephadex G75 column measured $3.2 \times 58 \mathrm{~cm}$. Flow rate was $31 \mathrm{ml} / \mathrm{hr}$ and collections were $4.7 \mathrm{ml} /$ tube. The $\mathrm{X}, \mathrm{Y}$, and $\mathrm{Z}$ peaks are indicated.

room temperature. Storage of the supernatant at $-20^{\circ} \mathrm{C}$ for 2 months did not alter the pattern of BSP binding.

The heat stability of the anion-binding protein fractions is shown in Fig. 2. Over $50 \%$ of BSP binding by $\mathrm{Y}$ was destroyed by preheating of the supernate to $50^{\circ} \mathrm{C}$ for $10 \mathrm{~min}$, whereas there was little change in $Z$ until the temperature exceeded $60^{\circ} \mathrm{C}$.

The elution pattern of liver supernate from a Gunn rat is shown in Fig. 3. When absorption at $460 \mathrm{~m} \mu$ was used to indicate possible bile pigment, three peaks, designated as $\mathrm{X}, \mathrm{Y}$, and $\mathrm{Z}$, were prominent. The MalloyEvelyn (14) estimation of bilirubin correlated with 460 $\mathrm{m} \mu \mathrm{OD}$ in $\mathrm{Y}$ and $\mathrm{Z}$ fractions but not in the $\mathrm{X}$ fraction. In the $\mathrm{X}$ fraction, the reaction was only weakly positive suggesting that the absorption at $460 \mathrm{~m} \mu$ was mainly due to yellow pigments other than bilirubin.

Three methods were used to demonstrate that the binding by $\mathrm{Y}$ and $\mathrm{Z}$ fractions of bilirubin- ${ }^{8} \mathrm{H}$ and, by inference, the other organic anions studied, was not due to albumin. As shown in Fig. 4, bilirubin- ${ }^{3} \mathrm{H}$ counts in the region labeled albumin, but not in the $Y$ and $Z$ fractions, were precipitated immunologically by addition of rabbit anti-rat albumin gamma globulin. The addition of purified rat albumin and BSP to a rat liver supernate in vitro accentuated BSP binding by the presumed albumin peak but did not alter that of the $\mathrm{Y}$ and $\mathrm{Z}$ fractions. In the former experiment as well as with gel filtration of normal rat liver supernate, the lyophilized presumed albumin fraction, but not $\mathrm{Y}$ and $\mathrm{Z}$ fractions, contained a protein which migrated as authentic rat albumin on acrylamide gel electrophoresis.
After addition of BSP in vitro, $\mathrm{Y}$ and $\mathrm{Z}$ fractions were not present in Sephadex G75 elution patterns of supernatant proteins from rat kidney, heart, brain, spleen, stomach, colon, skeletal muscle, plasma, or bile. $Y$ and $Z$ anion-binding protein fractions were identified by their respective elution position when compared with $Y$ and $Z$ from rat liver run on the same column under the same conditions. A fraction was regarded as present

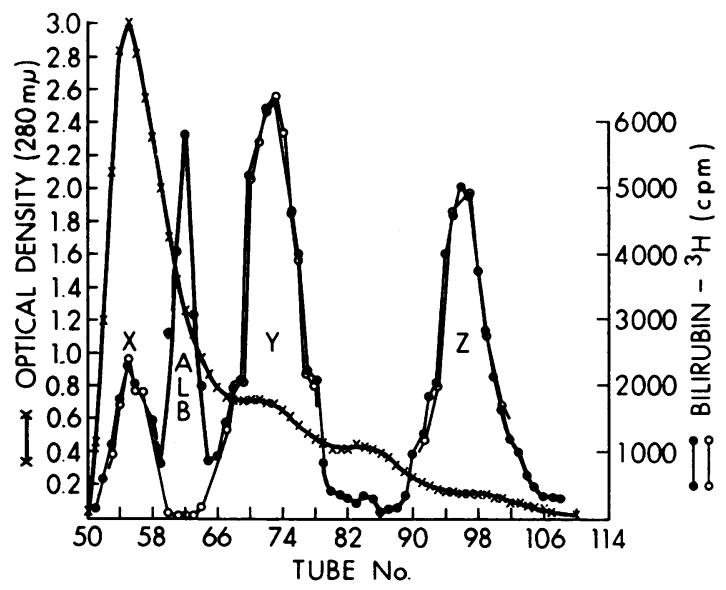

Figure 4 Bilirubin- ${ }^{8} \mathrm{H}(\mathrm{cpm})$ in $\mathrm{X}$, albumin (ALB) $\mathrm{Y}$, and $\mathrm{Z}$ fractions before (-C) and after ( $\mathrm{O}-\mathrm{O})$ precipitation of albumin with rabbit anti-rat albumin gamma globulin. Bilirubin- ${ }^{8} \mathrm{H}(5 \mu \mathrm{c})$ added to the supernate from $5.5 \mathrm{~g}$ Gunn rat liver was eluted from a Sephadex G75 column $(3.2 \times 85 \mathrm{~cm})$ at a flow rate of $36 \mathrm{ml} / \mathrm{hr}, 4.8 \mathrm{ml} /$ tube. Protein is indicated by OD $280 \mathrm{~m} \mu$. For further details see text. 

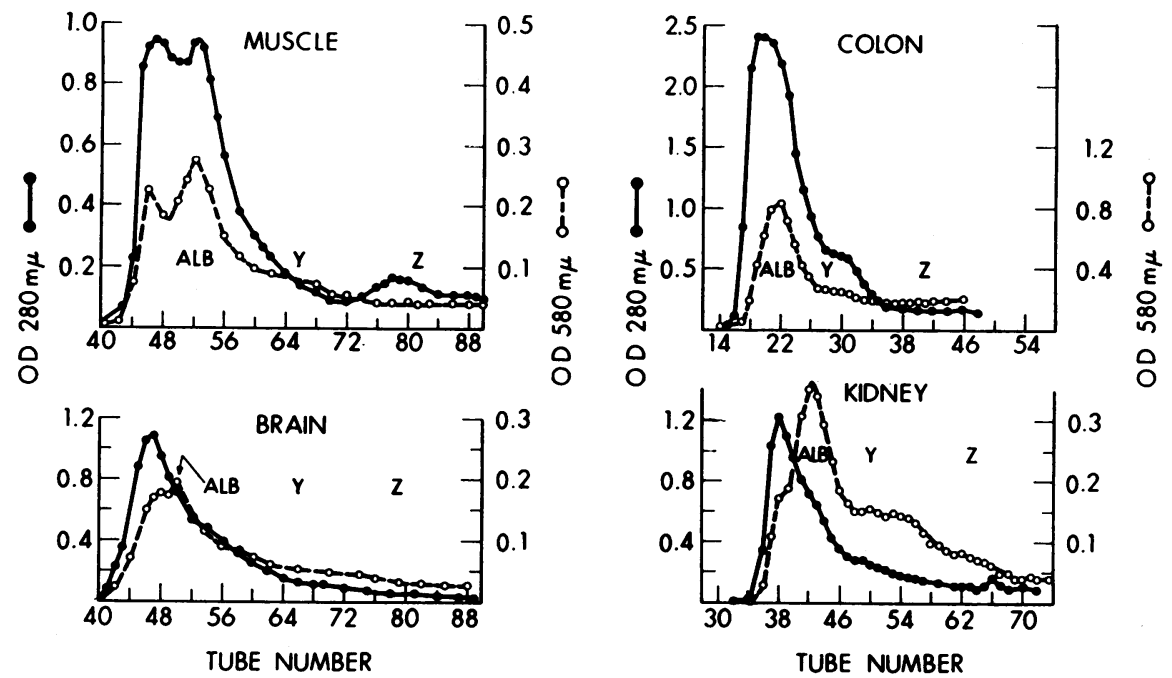

FIGURE 5 The elution pattern of protein and BSP from the supernate of various tissues: $3.34 \mathrm{~g}$ muscle with $12 \mu$ moles BSP, Sephadex G75 $(3.2 \times 92 \mathrm{~cm})$, flow rate $6 \mathrm{ml} /$ tube, $40 \mathrm{ml} / \mathrm{hr} ; 1.0 \mathrm{~g}$ colon $+6 \mu$ moles BSP, Sephadex G75 $(2.5 \times 33 \mathrm{~cm})$ flow rate $3 \mathrm{ml} /$ tube, $20 \mathrm{ml} / \mathrm{hr} ; 1.4 \mathrm{~g}$ kidney $+6 \mu$ moles BSP, Sephadex G75 $(3.2 \times 56 \mathrm{~cm})$, flow rate $4.3 \mathrm{ml} /$ tube, $29.4 \mathrm{ml} / \mathrm{hr}$; and $1.5 \mathrm{~g}$ brain $+3 \mu$ moles BSP, Sephadex G75 $(2.5 \times 36 \mathrm{~cm})$, flow rate $1.6 \mathrm{ml} /$ tube, $10.8 \mathrm{ml} / \mathrm{hr}$. Optical density at $280 \mathrm{~m} \mu$ indicates protein and at 580 $\mathrm{m} \mu$ after alkalinization indicates BSP. The expected position of albumin, $\mathrm{Y}$, and $\mathrm{Z}$ in these columns is shown. For other details see text.

when a well defined anion peak above the base line was present. Examples from skeletal muscle, brain, colon, and kidney are shown in Fig. 5. The $\mathrm{Y}$ fraction was not present in supernatant fraction of jejunum or ileum, however, $\mathrm{Z}$ was prominent. A study using the distal small intestine is shown in Fig. 6 . BSP binding by $Z$ was associated with the mucosa. The small peak seen in the submucosal, muscular, and serosal fraction was attributed to mucusal contamination (Fig. 6).

Prominent $\mathrm{Y}$ and $\mathrm{Z}$ BSP-binding protein fractions were present in liver supernate from homogenates of adult rats (Sprague Dawley, Wistar. and Gunn strains), guinea pigs (Hartley), monkeys (Rhesus), mice (C57BL/6, W/Wv, DBA/2J, Dw/dw, and LG/J), and man. $\mathrm{Y}$ and $\mathrm{Z}$ fractions were also present in the supernate obtained from isolated rat hepatocytes. Normal and mutant Southdown sheep had comparable Y and Z BSP binding fractions. Representative studies are shown in Fig. 7.

Although the pattern always remained the same, the amount of BSP bound by the $\mathrm{Y}$ and $\mathrm{Z}$ fractions varied with the size of the columns and the amount of protein added. These effects are shown in Table I. The results expressed as micromoles BSP bound by each fraction per gram liver parallel those expressed as micromoles BSP bound per milligram protein in the peak tubes. When the experimental conditions were constant, the results were reproducible. Large changes in column size or in the amount of protein added considerably altered quantitation of the bound anion particularly by the $\mathrm{Y}$ fraction.

When increasing quantities of BSP were added to adiquots of the same rat liver supernate in vitro and the dye-binding protein fractions were eluted from

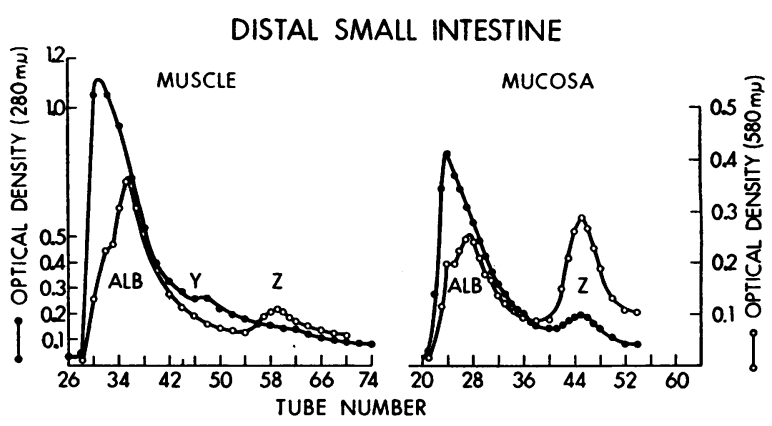

FIGURE 6 The elution pattern of protein (ON $280 \mathrm{~mm}$ ! and BSP (OD $580 \mathrm{~m} \mu$ after alkalinization) from supernate from distal half of small intestine of two normal adult rats (see text for procedural details). Muscle shows the study with all the residual tissues after scraping off the mucosa. BSP ( $6 \mu$ moles) was added to the muscle supernate and fractionated into $5.0 \mathrm{ml}$ samples on Sephadex G75 $(3.2 \times 54$ $\mathrm{cm})$ at a flow rate of $33.4 \mathrm{ml} / \mathrm{hr}$. Tube Nos. 59 and 60 , representing the $Z$ peak, contained $0.0095 \mu$ moles $\mathrm{BSP} / \mathrm{mg}$ protein. BSP, $6 \mu$ moles, was added to the mucosal supernate which contained $4.3 \mathrm{mg}$ protein. This was eluted from Sephadex G75 $(2.5 \times 37 \mathrm{~cm})$ at a flow rate $19.3 \mathrm{ml} / \mathrm{hr}$, collections $2.9 \mathrm{ml} /$ tube. Tubes 45 and 46 , representing the $Z$ peak, contained $0.0214 \mu$ moles $\mathrm{BSP} / \mathrm{mg}$ protein. 
Sephadex G75, the dye was preferentially bound to the $\mathrm{Y}$ fraction until a concentration of $0.012 \mu$ moles BSP/ $\mathrm{mg}$ protein was attained after which the dye was progressively bound to the $Z$ fraction (Fig. 8). A similar pattern was observed as a function of time after intravenous injection of BSP (Fig. 8). In these rats, the th for plasma BSP was $3.7 \mathrm{~min}$. At a dose of $6 \mu$ moles $\mathrm{BSP} / 100 \mathrm{~g}$, relatively low concentrations of BSP were found in the $Z$ fraction. At higher dosage, a greater concentration was found on $Z$ while the plateau for $Y$ remained. In the first $3 \mathrm{~min}$ after injection, BSP on the $\mathrm{Y}$ and $\mathrm{Z}$ fractions accounted for $75 \%$ of BSP found in the original supernate. Therefore, both in vivo and in vitro, there was preferential binding of $B S P$ to $Y$ before binding to $Z$ fraction occurred.

Organic anion binding by $\mathrm{Y}$ and $\mathrm{Z}$ fractions after addition of ICG, Evans blue, and BSP in vitro to aliquots of normal rat liver supernate is shown in Table II. The binding of each organic anion to $Y$ fraction was evident. Even in the presence of $5.2 \mu$ moles of Evans blue, binding of this anion by the $Z$ fraction was negligible when compared with the binding of the other organic anions. A prominent $\mathrm{X}$ peak was seen with ICG and Evans blue, indicating greater nonspecific binding of these anions by high molecular weight proteins. A different pooled supernate was used for studies of bilirubin binding in vitro but the results were comparable with those observed with the other organic anions although the quantity of pigment bound was less (Table II).

The distribution of ICG and Evans blue in $Y$ and $Z$ supernatant fractions of normal rat liver after intravenous injection of the organic anion is shown in Table III. After intravenous injection of ICG, only traces of
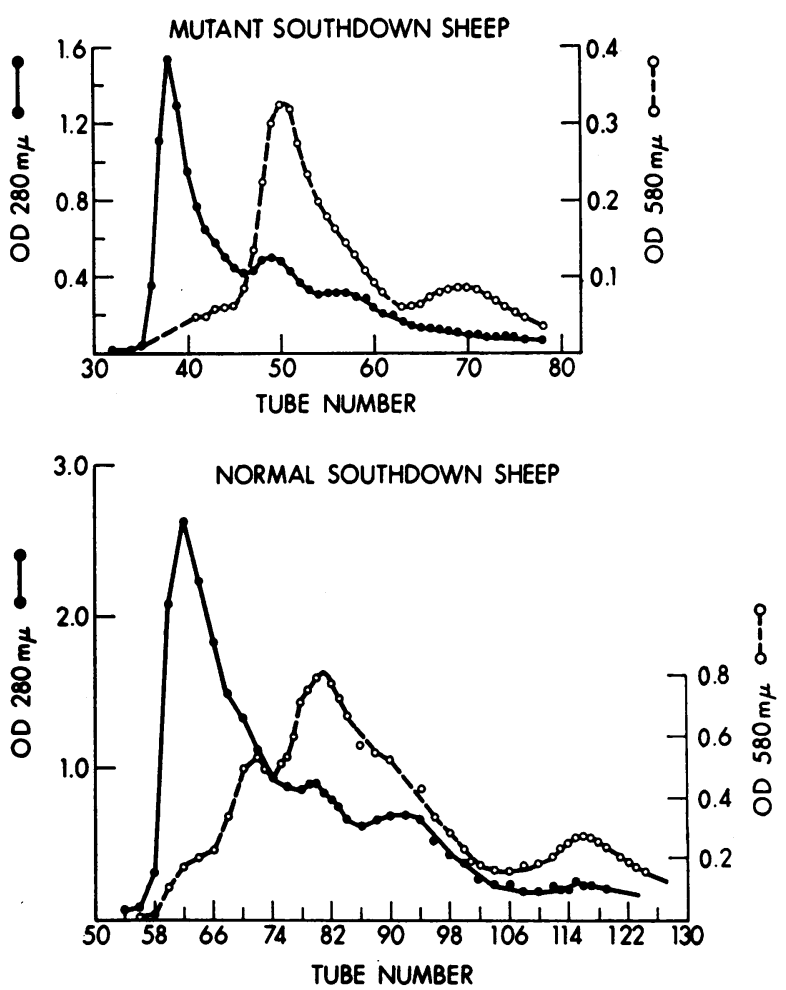

Figure 7 The elution pattern of BSP (OD $580 \mathrm{~m} \mu$ after alkalinization) and protein (OD $280 \mathrm{~m} \mu$ ) from the supernate from normal and mutant Southdown sheep liver with BSP added in vitro: In the mutant, supernate was derived from $1.43 \mathrm{~g}$ liver, $3 \mu$ moles BSP was added, and the mixture was eluted from Sephadex G75 $(3.2 \times 54 \mathrm{~cm})$ at a flow rate $29 \mathrm{ml} / \mathrm{hr}$. Each tube contained $4.3 \mathrm{ml}$. In the normal, supernate was derived from $5.3 \mathrm{~g}$ liver, $15 \mu$ moles BSP was added, and the mixture was eluted from a column $3.2 \times 96 \mathrm{~cm}$ at a flow rate of $33 \mathrm{ml} / \mathrm{hr}$. Each tube contained $4.4 \mathrm{ml}$.

TABLE I

Variables in BSP Binding by $Y$ and $Z^{*}$

\begin{tabular}{|c|c|c|c|c|c|c|}
\hline \multirow{2}{*}{$\begin{array}{l}\text { Column } \\
\text { size }\end{array}$} & \multirow{2}{*}{$\begin{array}{l}\text { No. of } \\
\text { experi- } \\
\text { ments }\end{array}$} & \multirow{2}{*}{$\begin{array}{c}\text { Equiv- } \\
\text { alent } \\
\text { weight } \\
\text { of liver } \\
\text { used }\end{array}$} & \multicolumn{2}{|c|}{ BSP bound per liver } & \multicolumn{2}{|c|}{ BSP bound per protein, peak tube } \\
\hline & & & $\mathbf{Y}$ & $Z$ & $\mathbf{Y}$ & $z$ \\
\hline $\mathrm{cm}$ & & $g$ & \multicolumn{2}{|c|}{ 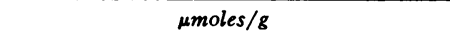 } & \multicolumn{2}{|c|}{ $\mu m o l e s / m g$} \\
\hline $2.5 \times 36.8$ & 6 & 1 & $0.135 \pm 0.002$ & $0.106 \pm 0.003$ & $0.0232 \pm 0.0007$ & $0.0495 \pm 0.0013$ \\
\hline $2.5 \times 36.8$ & 4 & 0.5 & $0.089 \pm 0.002$ & $0.085 \pm 0.003$ & $0.0135 \pm 0.0007$ & $0.0387 \pm 0.0004$ \\
\hline $3.2 \times 59$ & 6 & 2 & $0.129 \pm 0.006$ & $0.097 \pm 0.004$ & $0.0175 \pm 0.0005$ & $0.0393 \pm 0.0024$ \\
\hline $3.2 \times 59$ & 2 & 1 & $0.072, \quad 0.069$ & $0.081, \quad 0.077$ & $0.0084, \quad 0.0089$ & $0.028, \quad 0.033$ \\
\hline $3.2 \times 91$ & 3 & 2 & $0.073 \pm 0.003$ & $0.081 \pm 0.002$ & $0.0133 \pm 0.001$ & $0.0384 \pm 0.0054$ \\
\hline
\end{tabular}

BSP, sulfobromophthalein.

* The variation in binding of BSP ( $3.0 \mu$ moles/g) added in vitro to supernate of rat liver using columns of various sizes and different amounts of supernatant protein. Supernate from each $\mathrm{g}$ liver contained $40 \mathrm{mg}$ protein. Results are shown as mean 土SEM. Binding is expressed as $\mu$ moles BSP bound by the $\mathrm{Y}$ and $\mathrm{Z}$ fractions per $\mathrm{g}$ liver calculated by triangulation of the OD $580 \mathrm{~m} \mu$ peaks. Binding is also expressed as $\mu$ moles BSP bound per mg protein in the elution tubes that contained the maximal amount of BSP. Other procedural details were as described in the text. 
dye were found in the $Z$ fraction, although substantial amount of dye were bound to the $Y$ fraction. After intravenous injection of Evans blue, no significant amount of the dye was bound to either $\mathrm{Y}$ and $\mathrm{Z}$ fractions. The binding of bilirubin to $\mathrm{Y}$ and $\mathrm{Z}$ supernatant fractions of normal rat liver $5 \mathrm{~min}$ after intravenous administration of unconjugated bilirubin is shown in Fig. 9. When the tracer dose of bilirubin was administered, binding was predominantly to the $\mathrm{Y}$ fraction; however, when the larger dose of bilirubin was injected, bile pigment was bound to both $\mathrm{Y}$ and $\mathrm{Z}$ fractions.

The effect of several drugs thought to interefere with hepatic uptake of bilirubin or BSP was investigated in vitro and in vivo. BSP binding by $\mathrm{Y}$ and $\mathrm{Z}$ fractions of normal rat liver supernate with and without increasing doses of flavaspidic acid or bunamiodyl added to BSPsupernate mixtures in vitro is shown in Fig. 10. BSP was selectively displaced from the $Z$ fraction by both drugs but not from the $\mathrm{Y}$ fraction except at the highest concentration of bunamiodyl used. Displacement of BSP from $Z$ was about complete when the molar ratio of flavaspidic acid to BSP was $0.3: 1$. In other studies, there was no displacement of BSP from $\mathrm{Y}$ when the molar ratio was $2.3: 1$ but considerable displacement at very high ratios $(9.3: 1)$. The effect of novobiocin, probenecid, and $\mathrm{X} 5079 \mathrm{C}$ on the binding of BSP to $\mathrm{Y}$ and $Z$ fractions in vitro is shown in Table IV. Under the conditions of the experiment, these drugs had no effect whether the results are expressed as micromoles BSP bound per fraction or as micromoles BSP per milligram protein in the peak tubes from the $\mathrm{Y}$ and $\mathrm{Z}$ fractions. Similarly, taurocholic acid did not reduce the binding of BSP to either fraction until the molar ratio
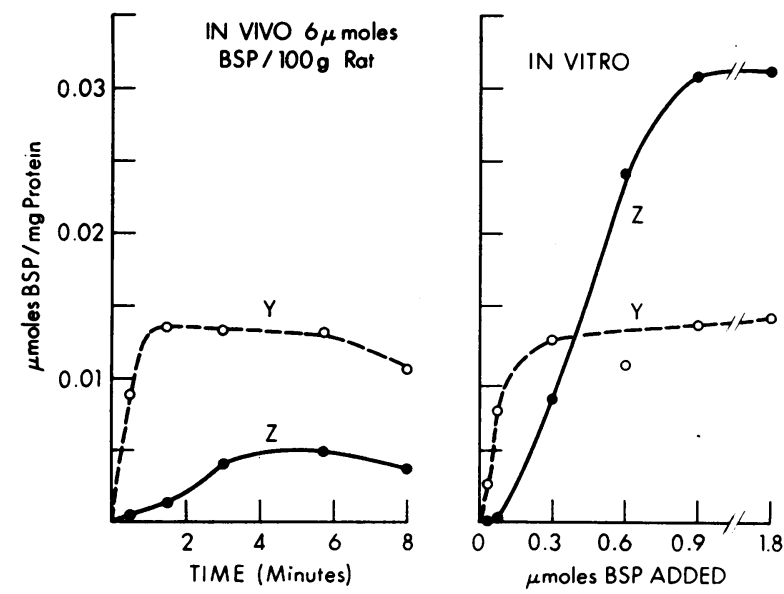

FIgURe 8 BSP bound per milligram protein in the peak tubes of the $\mathrm{Y}$ and $\mathrm{Z}$ fractions after injection of BSP in vivo or addition in vitro. Rat liver supernate was eluted from a Sephadex G75 $(3.2 \times 51.5 \mathrm{~cm})$ at a flow rate of $34.8 \mathrm{ml} / \mathrm{hr} 5.2 \mathrm{ml} /$ tube.
TABLE II

Binding of Various Organic Anions by $Y$ and $Z$ Fractions of Rat Liver Supernate In Vitro*

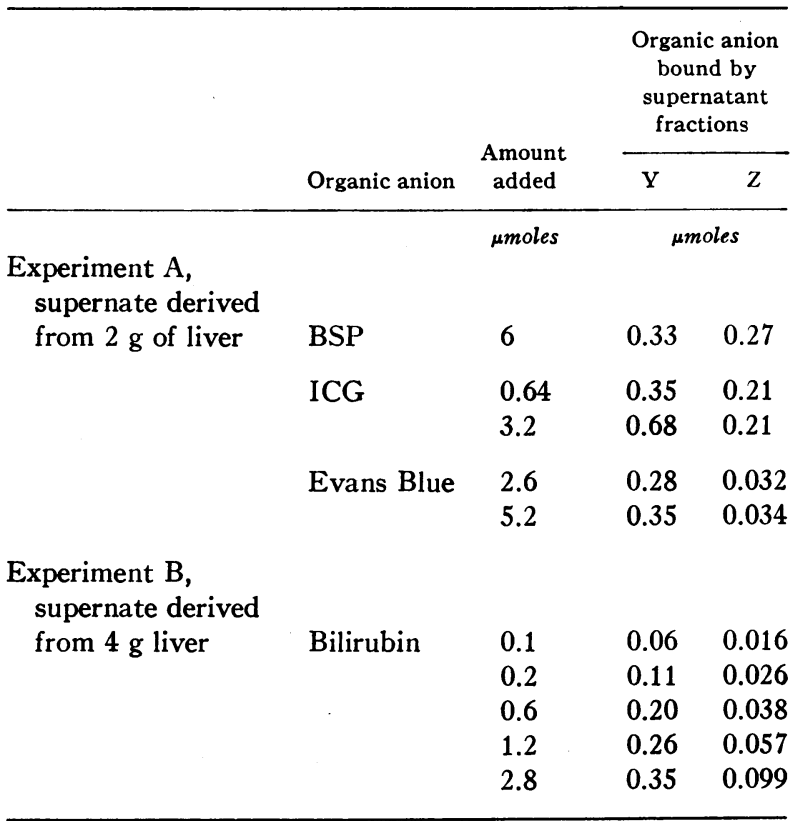

ICG, indocyanine green.

* The supernate-anion mixtures were eluted from columns 3.2 $\times 59 \mathrm{~cm}$. Other procedural details were as described in the text.

of taurocholic acid to BSP was 12 , when there was a slight displacement of BSP from $Z$ (Fig. 11).

The effect of administration of flavaspidic acid, bunamiodyl, iodipamide, novobiocin, and $\mathrm{X} 5079 \mathrm{C}$ in vivo on the binding of bilirubin to $\mathrm{Y}$ and $\mathrm{Z}$ supernatant frac-

TABLE III

Binding of ICG and Evans Blue by $Y$ and $Z$ Fractions from Rat Liver Supernate after Intravenous Administration of the Organic Anion*

\begin{tabular}{|c|c|c|c|c|}
\hline \multirow[b]{2}{*}{ Organic anion } & \multirow[b]{2}{*}{ Dosage } & \multirow{2}{*}{$\begin{array}{l}\text { Time of } \\
\text { sacrifice }\end{array}$} & \multicolumn{2}{|c|}{$\begin{array}{l}\text { Organic anion } \\
\text { binding by super- } \\
\text { natant fractions }\end{array}$} \\
\hline & & & $\mathrm{Y}$ & $z$ \\
\hline & $\begin{array}{c}\text { 4moles/ } \\
100 \mathrm{~g}\end{array}$ & $\min$ & \multicolumn{2}{|c|}{ umoles } \\
\hline \multirow[t]{3}{*}{ ICG } & 4.3 & 8 & 0.074 & 0 \\
\hline & 4.0 & 10 & 0.071 & 0.004 \\
\hline & 3.7 & 15 & 0.098 & 0.004 \\
\hline \multirow[t]{2}{*}{ Evans Blue } & 3.4 & 16 & $\mathbf{0}$ & $\mathbf{0}$ \\
\hline & 3.15 & 45 & 0 & 0 \\
\hline
\end{tabular}

* Supernate derived from $2 \mathrm{~g}$ liver was eluted from columns $3.2 \times 57.6 \mathrm{~cm}$. Flow rate of $34.7 \mathrm{ml} / \mathrm{hr} ; 5.2 \mathrm{ml} /$ tube. Other procedural details were as described in the text. 


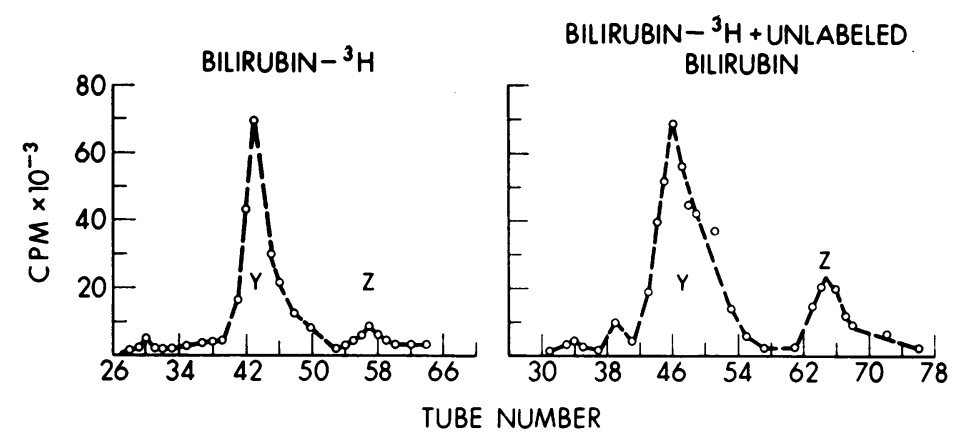

FIGURE 9 The elution pattern of bilirubin- ${ }^{3} \mathrm{H}$ in normal rat liver supernate after intravenous injection of $150,000 \mathrm{cpm}$ alone and with $6.2 \mu$ moles unlabeled bilirubin. $\mathrm{Y}$ and $\mathrm{Z}$ peaks are identified. Supernate derived from 2.7 and $2.9 \mathrm{~g}$ liver, respectively.

tions was studied in Gunn rats. The results are presented in Table V. After administration of flavaspidic acid, bunamiodyl, or iodipamide there was selective displacement of bilirubin from the $Z$ fraction but not from $Y$. This is reflected by a significant $(P<0.01)$ decrease in bilirubin bound by $Z$ and accompanied by reduction in the supernate bilirubin concentration. No significant effect was observed after administration of either novobiocin or $\mathrm{X} 5079 \mathrm{C}$.

\section{DISCUSSION}

Localization of injected radioactive bilirubin in the supernatant fraction of liver cell homogenates $(1,2)$ focused attention on the possible role of soluble proteins in the transfer of bilirubin and other organic anions from plasma into the liver. Gel filtration was chosen as the initial method of protein separation because it does not disrupt the anion-protein bond and permits binding proteins to be identified by the presence of organic anion. Other techniques of protein separation, such as ion exchange chromatography or electrophoresis (2), dissociate the anion-protein bond and remove the identifying label.

Sephadex G75 fractionation of $110,000 \mathrm{~g}$ liver supernate separates relatively small molecular weight proteins and reveals localization of BSP binding proteins to two main fractions called $\mathrm{Y}$ and $\mathrm{Z}$. This pattern occurs under a variety of experimental situations, including changes in buffer, $\mathrm{pH}$, molarity, column size, and amount of protein fractionated. The binding was reproducibly quantitated when column size and amount of applied protein were kept constant. BSP binding by $\mathrm{Y}$ was altered more than BSP binding by $Z$ with changes in column size or amount of protein whether expressed as micromoles BSP bound by each fraction or as micromoles BSP per milligram protein in the peak tubes (Table I). On Sephadex columns, bound anion is in equilibrium with free anion and an increase in length of the column permits further dissociation. Sephadex is not inert in relation to BSP and other organic anions. When two binding proteins of different molecular weights are separated by elution, the smaller protein is

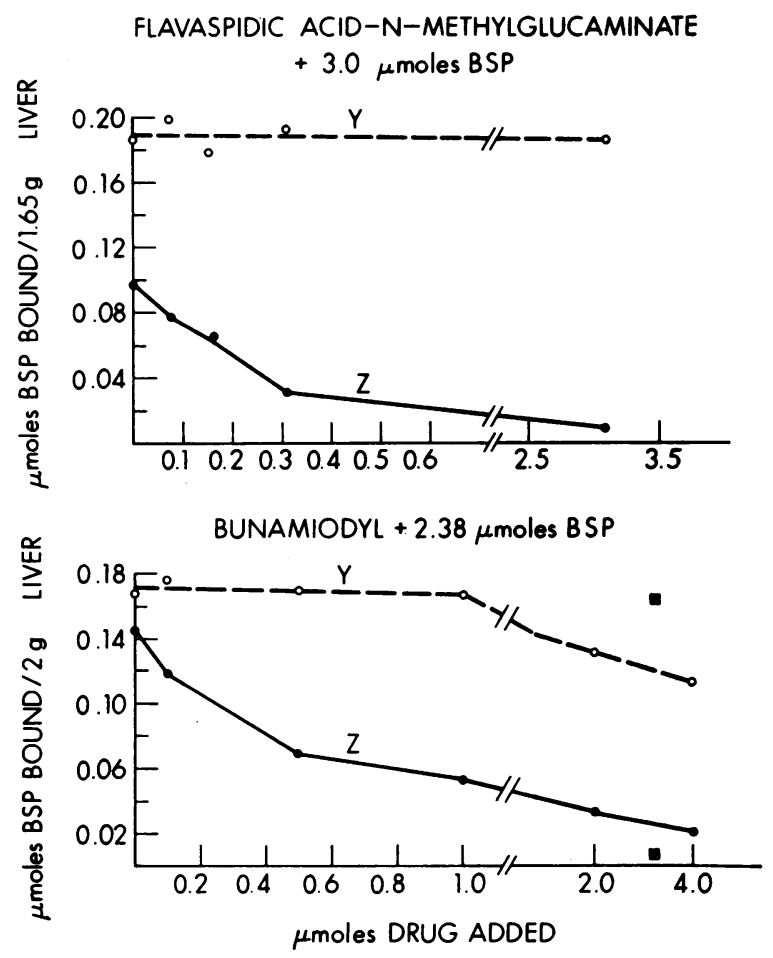

FIGURE 10 BSP bound by $Y$ and $Z$ fractions in the presence of flavaspidic acid- $N$-methylglucaminate or bunamiodyl. The aliquots of supernate for the flavaspidic acid studies were derived from $1.65 \mathrm{~g}$ liver, containing $40 \mathrm{mg}$ protein, and $3.0 \mu$ moles BSP was added. In the studies with bunamiodyl, each aliquot of supernate was derived from $2.0 \mathrm{~g}$ liver containing $58 \mathrm{mg}$ protein and $2.38 \mu$ moles BSP was added. $\square$ and represent a single study with flavaspidic acid and the second supernate, Column size, $3.2 \times 52-54 \mathrm{~cm}$; flow rate, $32-33.4 \mathrm{ml} / \mathrm{hr}$; and collections, $4.8-5 \mathrm{ml} /$ tube. 
"fed" free anion dissociating from the higher molecular weight protein as elution continues. This tends to maintain the amount of anion bound by the smaller protein when column length is increased. The effect is demonstrated in Table I. Thus, comparative quantitative studies are possible under defined conditions, but only qualitative comparisons are valid when the results from columns of different sizes or with different amounts of applied protein are compared.

$Z$ protein was relatively heat stable and withstood a temperature of $60^{\circ} \mathrm{C}$ for $10 \mathrm{~min}$ without being precipitated. $\mathrm{Y}$ protein was precipitated by temperatures over $50^{\circ} \mathrm{C}$. This correlates with Hargreaves' finding that the uptake of unconjugated bilirubin by rat liver slices in vitro is greatly diminished at $50^{\circ} \mathrm{C}(23)$.

The Gunn rat was used as a model because it has endogenously produced, relatively constant unconjugated hyperbilirubinemia (10). In this mutant, $60-70 \%$ of hepatic bilirubin is in the supernatant fraction $(2,24)$. Gel filtration of the supernatant fraction separated the yellow pigments as determined by absorption at $460 \mathrm{~m} \mu$ into three peaks designated $\mathrm{X}, \mathrm{Y}$, and $\mathrm{Z}$. The yellow pigment in the $\mathrm{X}$ region was not predominantly bilirubin, as it only gave a weak reaction in the Malloy-Evelyn estimation. The $\mathrm{X}$ fraction has not been further investigated.

Previous studies suggested that bilirubin in the supernatant fraction is associated with a protein immunologically (7) and electrophoretically (2) distinct from albumin. The albumin concentration in the supernate from isolated liver cells is only $0.055 \mathrm{mg} / \mathrm{g}$ liver, al-

TABLE IV

Effect of Various Drugs on BSP Binding by $Y$ and $Z$ Supernatant Fractions of Normal Rat Liver In Vitro*

\begin{tabular}{|c|c|c|c|}
\hline \multirow[b]{2}{*}{ Organic anion } & \multirow[b]{2}{*}{ Amount added } & \multicolumn{2}{|c|}{$\begin{array}{l}\text { BSP bound per } \\
\text { supernatant } \\
\text { fraction }\end{array}$} \\
\hline & & $\mathrm{Y}$ & $z$ \\
\hline & & \multicolumn{2}{|c|}{ umoles } \\
\hline \multirow[t]{4}{*}{ Novobiocin $\ddagger$} & 0 & 0.121 & 0.137 \\
\hline & 0 & 0.124 & 0.148 \\
\hline & 3.12 umoles & 0.135 & 0.159 \\
\hline & 15.60 umoles & 0.146 & 0.139 \\
\hline \multirow[t]{2}{*}{ Probenecid§ } & 0 & 0.190 & 0.144 \\
\hline & $3.12 \mu$ moles & 0.185 & 0.144 \\
\hline \multirow[t]{2}{*}{ X5079C\& } & $0.086 \mathrm{mg}$ & 0.206 & 0.186 \\
\hline & $0.86 m g$ & 0.177 & 0.168 \\
\hline
\end{tabular}

* Each study was performed with an aliquot of pooled supernate derived from $2.26 \mathrm{~g}$ liver containing $50 \mathrm{mg}$ protein and $2.38 \mu$ moles BSP added. Other procedural details were as described in the text.

$\ddagger$ The column size for novobiocin was $3.2 \times 91.5 \mathrm{~cm}$.

$\S$ Column size for probenecid was $3.2 \times 52-54 \mathrm{~cm}$.

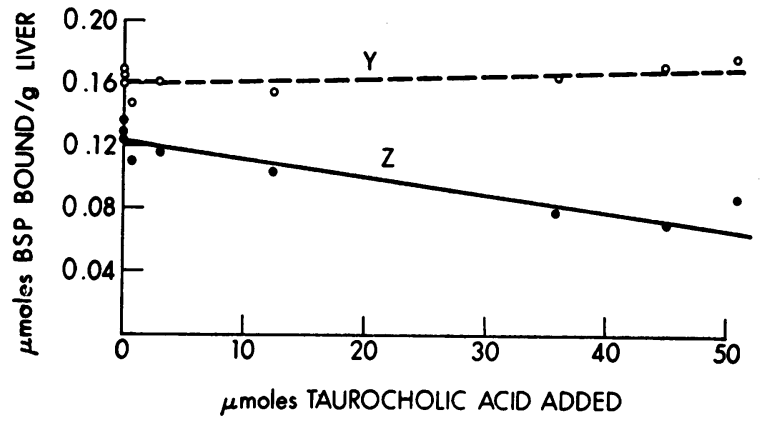

FIGURE 11 BSP bound by $\mathrm{Y}$ and $\mathrm{Z}$ fractions in the presence of taurocholic acid. Aliquots of supernate from $1 \mathrm{~g}$ rat liver contained $45.6 \mathrm{mg}$ protein and $3.0 \mu$ moles BSP was added. Columns size $2.5 \times 37 \mathrm{~cm}$, flow rate $20 \mathrm{ml} / \mathrm{hr}$, and $3 \mathrm{ml} /$ tube.

though it is higher in supernate prepared from perfused liver because of trapping of plasma albumin (6). This small amount of albumin is insufficient to bind even physiologic hepatic levels of bilirubin (1). In addition, intracellular albumin is predominantly found in the microsomal fraction of liver homogenates (6), whereas bilirubin is predominantly in the supernatant fraction (2). Nevertheless, it was important to demonstrate that anion binding by the $\mathrm{Y}$ and $\mathrm{Z}$ fraction was not due to albumin. This was done by three separate techniques which demonstrate that the small amount of albumin in the supernatant fractions was eluted separately from the $\mathrm{Y}$ and $\mathrm{Z}$ fractions and was not responsible for their anion binding properties.

The similar pattern of bilirubin and BSP binding by $\mathrm{Y}$ and $\mathrm{Z}$ fractions in vivo or in vitro suggests that they are bound by the same proteins and that these proteins may have a physiologic role in the transfer process. Indocyanine green, which is rapidly taken up by the liver and competes with BSP in this process (25), was also bound to $\mathrm{Y}$ and $\mathrm{Z}$ proteins in vitro.

Evans blue is slowly taken up by the liver in vivo $(26,27)$. After intravenous injection of this anion into a rat, no binding to $Y$ and $Z$ fractions of liver supernate was demonstrated. However, after addition of Evans blue in vitro, the amount of anion binding to $\mathrm{Y}$ was comparable to that found with BSP or ICG under the same conditions but the binding by $Z$ was less than $16 \%$ of that found with the other anions. This suggests that the ability of an anion to bind to $\mathrm{Y}$ in vitro is not the major determinant of anion selectivity by the liver. Some selectivity in the uptake process may reside in the $Z$ protein or in the cell membrane.

Nonspecific binding by many proteins was responsible for the pattern seen in nonhepatic tissues which lack $Y$ and $Z$ BSP binding fractions. The main binding peak in some tissues was due to albumin which had not been removed by perfusion (Fig. 5). 
TABLE V

The Effect of Various Drugs Injected Intravenously into Gunn Rats on the Amount of Bilirubin Bound by Supernatant Fractions $Y$ and $Z^{*}$

\begin{tabular}{|c|c|c|c|c|c|c|}
\hline \multirow[b]{2}{*}{ Drug } & \multirow[b]{2}{*}{$\begin{array}{l}\text { No. of } \\
\text { studies }\end{array}$} & \multirow[b]{2}{*}{ Dose } & \multirow[b]{2}{*}{ Plasma bilirubin } & \multirow[b]{2}{*}{$\begin{array}{c}\text { Supernate } \\
\text { bilirubin }\end{array}$} & \multicolumn{2}{|c|}{ Bilirubin bound } \\
\hline & & & & & $\mathrm{Y}$ & $z$ \\
\hline & & umoles/ & $m g / m l$ & $m g / g$ & \multicolumn{2}{|c|}{$m g / t g$ liver } \\
\hline Control & 6 & - & $0.112 \pm 0.009$ & $0.028 \pm 0.002$ & $0.05 \pm 0.009$ & $0.085 \pm 0.006$ \\
\hline Flavaspidic acid $N$-methylglucaminate & 4 & 5 & $0.126 \pm 0.01$ & $0.023 \pm 0.003$ & $0.056 \pm 0.009$ & $0.039 \pm 0.007 \ddagger$ \\
\hline Bunamiodyl & 3 & 4.4 & $0.098 \pm 0.009$ & $0.023 \pm 0.002$ & $0.076 \pm 0.009$ & $0.031 \pm 0.009 \ddagger$ \\
\hline Iodipamide & 2 & 5 & $0.115, \quad 0.086$ & $0.021, \quad 0.020$ & $0.072, \quad 0.068$ & $0.051, \quad 0.042 \ddagger$ \\
\hline
\end{tabular}

Values shown are mean \pm SEM.

* Animals were sacrificed $30 \mathrm{~min}$ after injection. Supernate derived from $4 \mathrm{~g}$ liver was eluted from columns $3.2 \times 52-56 \mathrm{~cm}$ at a flow rate of $28-32 \mathrm{ml} / \mathrm{hr}$.

‡ Results significantly different from controls $P<0.01$ (Students 2 tailed $t$ test)

The discrete $Z$ BSP-binding fraction from small intestinal mucosa contrasted with the lack of localized anion-binding fractions in the other tissues studied. This correlates with the relative inability of the organs tested to take up bilirubin or BSP from the plasma. Brauer, Pessotti, and Krebs (28) have shown that the small intestine is one of the main extrahepatic sites of removal of BSP from plasma in dogs receiving continuous infusions of the dye. $Z$ in the small intestine may be an important factor in the intestinal absorption of organic anions which undergo an enterohepatic circulation (29-31).

In contrast, supernate from the liver of rats, mice, guinea pigs, sheep, monkeys, and man contained $\mathrm{Y}$ and Z BSP binding fractions. Quantitative comparison between the various species cannot be made as the studies were not performed under comparable conditions of sample and column size. However, despite these limitations, large differences, particularly in dye binding by $Z$ fractions from different species, were observed. The $Z$ fractions were very low in man and sheep when compared with rats, mice, and guinea pigs.

The binding studies with BSP and rat liver supernate on Sephadex G75 can only be interpreted within the limitations of the methodology. The protein fractions are impure and the anion-protein complex is continuously in equilibrium with unbound anion in the eluting buffer. Variables were controlled by using aliquots of one supernate, the same column, and buffer flow rates and by only changing the amount of BSP added. The results were consistent and suggest that the $\mathrm{Y}$ fraction has a greater affinity for BSP than does the $Z$ fraction, but neither support nor exclude sequential transfer of BSP from $\mathrm{Y}$ to $\mathrm{Z}$ or vice versa.

In studies in vivo, free and/or conjugated BSP may have been partially removed from the liver by perfusion because the dye is relatively water soluble. A compro- mise had to be reached between the disadvantage of leaving plasma containing albumin and BSP in the liver to interact with the $\mathrm{Y}$ and $\mathrm{Z}$ proteins after homogenization, and the loss of BSP by thorough perfusion. The binding of conjugated BSP to the $\mathrm{Y}$ and $\mathrm{Z}$ fraction has not been studied.

A number of drugs including flavaspidic acid (18, 19), bunamiodyl $(17,32)$, iodipamide (33), novobiocin $(20,21,34)$, probenecid $(22,35)$, and X5079C $(36,37)$ cause BSP and/or bilirubin retention in man and/or rats. In particular, flavaspidic acid and bunamiodyl interfere with the uptake process (17-19). Flavaspidic acid, bunamiodyl, and iodipamide preferentially displaced bilirubin in vivo and BSP in vitro from the $Z$ fraction wthout affecting the binding by $\mathrm{Y}$. When flavaspidic acid was mixed with BSP at a molar ratio of $0.1: 1$, it displaced over $\frac{2}{3}$ of the BSP from $Z$. Only at molar ratios above 4:1 was there any displacement of BSP from Y. Similarly with bunamiodyl, at a ratio of $0.8: 1$ most of the BSP on $Z$ was displaced but none from $Y$ until considerably higher ratios were reached.

The failure to demonstrate competition for binding between bilirubin or BSP and novobiocin, probenecid, or X $5079 \mathrm{C}$ may be interpreted in a number of ways. Only a limited number of tests were performed at selected times and doses which may have been inappropriate. Some of the drugs are known to have other sites of action in the transport of anions into the cell, e.g., novobiocin (34) inhibits bilirubin conjugation in vitro. These drugs may also compete at a site on the cell membrane as suggested by Cornelius, Ben-Ezzer, and Arias (38) who demonstrated that ICG, bilirubin, and flavaspidic acid compete with BSP for binding on liver cell membranes in vitro. Taurocholic acid did not displace BSP from $Y$ and $Z$ fractions in vitro except at very high doses (molar ratio approaching 10) (Fig. 11). 
This suggests that the $\mathrm{Y}$ and $\mathrm{Z}$ proteins are not nonspecific binders for any organic anion in liver cells.

Flavaspidic acid, bunamiodyl, and iodipamide displaced BSP and bilirubin from the $Z$ fraction. This suggests that each of these anions is bound at the same site(s) on $Z$ protein. The affinity of the $\mathrm{Y}$ fraction for BSP or bilirubin was higher than the affinity of the $Z$ fraction for these anions (Figs. 8 and 9).

It is not understood how flavaspidic acid or bunamiodyl impair hepatic uptake processes yet compete for binding to the $Z$ fraction which appears to have a lower affinity than the $\mathrm{Y}$ fraction for the transported anions.

The mutant Southdown sheep rediscovered by Cornelius and Gronwall (11) has impaired hepatic uptake of BSP, bilirubin, rose bengal, and ICG. As shown in Fig. 7 , there is no obvious difference between the binding patterns of supernate from the livers of normal and mutant sheep. The defect in mutant sheep may be in the plasma membrane of liver cells rather than in hepatic cytoplasmic organic anion acceptor proteins.

The transfer of bilirubin and other organic anions from plasma into the hepatic cell may depend on dissociation of the anion from albumin in the plasma, nonionic diffusion of free anion across the cell membrane, and subsequent binding by cytoplasmic proteins. In this system, specificity for organic anion uptake could reside in the binding characteristics of cytoplasmic receptor proteins. The affinity of organic anions for albumin and cytoplasmic proteins could be of the same or. der, as the hepatic cell is in a separate compartment in equilibrium with plasma across the cell membrane through the small concentration of unbound anion. The inability of many organs to extract bilirubin or BSP rapidly from plasma correlates well with their lack of $\mathrm{Y}$ and $\mathrm{Z}$ protein fractions. Some anion specificity in the binding process is suggested by the observations that bilirubin or BSP were displaced from the $Z$ fraction by some, but not all, of the drugs tested.

A second possibility is that the specificity for organic anion uptake is in the cell membrane and cytoplasmic acceptor proteins act as nonspecific anion binders in a manner comparable with albumin in plasma. Transport across the membrane would be by facilitated diffusion. Both of these models are consistent with the data of Goresky (39) who showed that on a single circulation there is rapid flux of BSP and bilirubin from the liver. The selectivity for different organic anions need not be the exclusive property of either the cell membrane or cytoplasmic proteins.

$\mathrm{Y}$ and $\mathrm{Z}$ proteins may have a general function relating to the uptake of many organic anions that are transferred from plasma into liver. The cytoplasmic protein fractions which bind metabolites of cortisol (40) and carcinogenic dyes $(41,42)$ have similiar characteristics and may be identical to the $\mathrm{Y}$ and $\mathrm{Z}$ fractions described here. Study of the binding characteristics of the $Y$ and $Z$ proteins is now possible with increased purification of the $\mathrm{Y}$ and $\mathrm{Z}$ fractions (in preparation).

These proteins provide a tool for study of the transfer of organic anions from blood to liver cell, as well as the mechanism of possible uptake defects in disorders characterized by unconjugated hyperbilirubinemia such as neonatal jaundice, hemolysis, and Gilbert's syndrome.

\section{ACKNOWLEDGMENTS}

We wish to express our grateful appreciation to Dr. Charles E. Cornelius of the School of Veterinary Medicine, Kansas State University, Manhattan, Kans. for providing the samples of mutant Southdown sheep liver; to Dr. Esa Aho of Turku, Finland for several generous gifts of flavaspidic acid- $N$-methylglucaminate; to Dr. Seldon Bernstein of the Jackson Memorial Laboratory, Bar Harbor, Maine for providing the inbred mice; to Dr. Theodore Peters of the Mary Imogene Basset Hospital, Cooperstown, N. Y. for the rabbit anti-rat albumin gamma globulin.

This research was supported by grants from the U. S. Public Health Service (AM 02019 and 2 TO1 AM 5384) and the New York Heart Association and Heart Fund, Inc.

\section{REFERENCES}

1. Brown, W. R., G. M. Grodsky, and J. V. Carbone. 1964. Intracellular distribution of tritiated bilirubin during hepatic uptake and excretion. Amer. J. Physiol. 207: 1237.

2. Bernstein, L. H., J. Ben Ezzer, L. Gartner, and I. M. Arias. 1966. Hepatic intracellular distribution of tritiumlabeled unconjugated and conjugated bilirubin in normal and Gunn rats. J. Clin. Invest. 45: 1194.

3. Overbeek, J. Th. G., C. L. J. Vink, and H. Deenstra. 1955. The solubility of bilirubin. Rec. Trav. Chim. PaysBas. 74: 81 .

4. Burnstine, R. C., and R. Schmid. 1962. Solubility of bilirubin in aqueous solutions. Proc. Soc. Exp. Biol. Med. 109: 356 .

5. Ostrow, J. D., and R. Schmid. 1963. The protein binding of ${ }^{11} \mathrm{C}$-bilirubin in human and murine serum. J. Clin. Invest. 42: 1286.

6. Peters, T., Jr. 1962. The biosynthesis of rat serum albumin. J. Biol. Chem. 237: 1181.

7. Grodsky, G. 1967. Studies in the uptake and intrahepatic transport of $\left({ }^{8} \mathrm{H}\right)$ bilirubin. In Bilirubin Metabolism. I. A. D. Bouchier and Barbara Billing, editors. Blackwell Scientific Publications Ltd., Oxford. 159.

8. Odell, G. B., J. C. Natzschka, and B. Storey. 1966. Bilirubin in the liver and kidney of jaundiced rats. Amer. J. Dis. Child. 112: 351 .

9. Howard, R. B., A. K. Christensen, F. A. Gibbs, and L. A. Pesch. 1967. The enzymatic preparation of isolated intact parenchymal cells from rat liver. J. Cell. Biol. 35: 675 .

10. Gunn, C. H. 1938. Hereditary acholuric jaundice in a new mutant strain of rats. J. Hered. 29: 137.

11. Cornelius, C. E., and R. R. Gronwall. 1968. Congenital photosensitivity and hyperbilirubinemia in Southdown sheep in the United States. Amer. J. Vet. Res. 29: 291.

12. Lowry, O. H., N. J. Rosebrough, A. L. Farr, and R. J. Randall. 1951. Protein measurement with the folin phenol reagent. J. Biol. Chem. 193: 265. 
13. Layne, E. 1957. Spectrophotometric and turbidimetric methods for measuring proteins. In Methods in Enzymology. S. P. Colowick and N. O. Kaplan, editors. Academic Press Inc., New York. 3: 447.

14. Malloy, H. T., and K. A. Evelyn. 1937. Determination of bilirubin with the photoelectric colorimeter. J. Biol. Chem. 119: 481.

15. Hargreaves, T. 1965. The estimation of bilirubin in liver. Clin. Chim. Acta. 11: 278.

16. Philp, J. R., G. M. Grodsky, and J. V. Carbone. 1961. Mercaptide conjugation in the uptake and secretion of sulfobromophthalein. Amer. J. Physiol. 200: 545.

17. Berthelot, P., and B. Billing. 1966. Effect of bunamiodyl on hepatic uptake of sulfobromophthalein in the rat Amer. J. Physiol. 211: 395.

18. Nosslin, B., and E. H. Morgan. 1965. The effect of phloroglucinol derivatives from male fern on dye excretion by the liver in the rabbit and rat. J. Lab. Clin. Med. 65: 891 .

19. Hammaker, L., and R. Schmid. 1967. Interference with bile pigment uptake in the liver by flavaspidic acid. Gastroenterology. 53: 31 .

20. Berthelot, P., and R. Fauvert. 1967. L'Excretion de bilirubine non conjugée dans la bile du rat. Modification de cette excrétion par la novobiocine. Rev. Fr. Etud. Clin. Biol. 12 : 702.

21. Erlinger, S., M. Emond, P. Berthelot, J. P. Bertamon, and R. Fauvert. 1966. Effects de la novobiocine sur la fonctionnement du foie. II. Etude experimentale. Rev. Fr. Etud. Clin. Biol. 11: 680.

22. Goetzee, A. E., T. G. Richards, and V. R. Tindall. 1960. Experimental changes in liver function induced by probenecid. Clin. Sci. (London). 19: 63.

23. Hargreaves, T. 1968. The Liver and Bile Metabolism. Appleton-Century-Crofts Inc., New York. 92.

24. Garay, E. A. R., and E. R. Dickson. 1967. Intrahepatic distribution of tritiated bilirubin in normal and Gunn rats: subcellular fractionation. Proc. Soc. Exp. Biol. Med. 125 : 1291

25. Hunton, D. B., J. L. Bollman, and H. N. Hoffman. 1961. Plasma removal of ICG and BSP. Effect of dosage and blocking agents. J. Clin. Invest. 40: 1648.

26. Miller, A. T. 1947. Excretion of the blue dye T-1824 in the bile. Amer. J. Physiol. 151: 229.

27. Stoelinga, G. B. A., and P. J. J. Van Munster. 1967. The behaviour of Evans Blue (Azo-dye T-1824) in the body after intravenous injection. Acta Physiol. Pharmacol. Neer. 14: 391.

28. Brauer, R. W., R. L. Pessotti, and J. S. Krebs. 1955. The distribution and excretion of $\mathrm{S}^{35}$ labelled sulfobromophthalein-sodium administered to dogs by continuous infusion. J. Clin. Invest. 34: 35 .

29. Tidball, C. S. 1964. Intestinal and hepatic transport of cholate and organic dyes. Amer. J. Physiol. 206: 239.

30. Lester, R., and R. Schmid. 1964. Intestinal bilerubin metabolism or absorption of bile pigments in man. $N$. Engl.J. Med. 270: 779.

31. Lorber, S. H., and H. Shay. 1952. Enterohepatic circulation of bromsulphalein. Gastroenterology. 20: 262.

32. Bolt, R. J., R. S. Dillon, and H. M. Pollard. 1961. Interference with bilirubin excretion by a gall bladder dye (bunamiodyl). N. Engl. J. Med. 265: 1043.

33. Billing, B. H., Q. Maggiore, and M. A. Cartter. 1963. Hepatic transport of bilirubin. Ann. N. Y. Acad. Sci. 111: 319.

34. Hargreaves, T., and G. H. Lathe. 1963. Inhibitory aspects of bile secretion. Nature (London). 200: 1172.

35. Blondheim, S. H. 1954. Effect of probenecid on excretion of BSP. J. Appl. Physiol. 7: 529.

36. Andriole, V. T., J. P. Utz, and S. M. Sabesin. 1961. Altered BSP metabolism in man induced by the antifungal agent X5079C. Amer. Rev. Resp. Dis. 84: 538.

37. Andriole, V. T. 1963. Altered BSP metabolism in the dog induced by the antifungal agent X5079C. J. Lab. Clin. Med. 61: 730

38. Cornelius, C., J. Ben-Ezzer, and I. M. Arias. 1967. Binding of sulfobromophthalein sodium (BSP) and other organic anions by isolated hepatic cell plasma membranes in vitro. Proc. Soc. Exp. Biol. Med. 124: 665.

39. Goresky, C. 1965. The hepatic uptake and excretion of sulfobromophthalein and bilirubin. Can. Med. Ass. J. 92: 851.

40. Morey, K. S., and G. Litwack. 1968. Cortisol metabolite binding protein (s) of liver cytoplasm. Fed. Proc. $27: 524$.

41. Sorof, S., E. M. Young, M. M. McCue, and P. L. Fetterman. 1963. Zonal electrophoresis of the soluble proteins of liver and tumor in azo dye carcinogenesis. Cancer Res. 23: 864.

42. Ketterer, B., P. Ross-Mansell, and J. K. Whitehead. 1967. The isolation of carcinogen binding protein from livers of rats given 4 dimethylaminoazobenzene. Biochem. J. 103: 316 . 